\title{
Komu patrí Mikuláš Šubić Zrínsky? (K inšpiračným zdrojom a ideovej koncepcii historického eposu Andreja Sládkoviča Gróf Mikuláš Šubić Zrínsky na Sihoti)
}

Ingrid Papp

PAPP, I.: Whose Is Mikuláš Šubić Zrínsky? (On the Sources of Inspiration and Conceptual Background of the Historical Epic Gróf Mikuláš Šubić Zrínsky na Sihoti [Count Nikola Šubić Zrinski at Sziget] by Andrej Sládkovič) SLOVENSKÁ LITERATÚRA, vol. 68, 2021, no. 4, pp. 432-441

DOI: https://doi.org/10.31577/slovlit.2021.68.4.4

ORCID ID: 0000-0002-0470-1360

Key words: national awareness, political ideology, Pan-Slavic identity, Nikola Šubić Zrinski (1508-1566), Nikola VII Zrinski (1620 - 1664), Andrej Sládkovič

Accounts of the character and deeds of Nikola IV Zrinski (1508-1566) who became renowned for his heroic guarding of Szigetvár in 1566 and of the work and life of his great-grandson Nikola VII Zrinski (1620 - 1664), a 17th-century baroque poet, had long played central roles in the building of national awareness and political ideology in Hungary. The Slavic inhabitants of the Kingdom of Hungary were familiar with the general who fought against the Ottoman Empire since the 16th century, but in the 19th century, in the context of the idea of Slavic mutuality and Pan-Slavism, this historical figure became more important. In 1866, Andrej Sládkovič (1820-1872) wrote a historical epic Gróf Mikuláš Šubić Zrínsky na Sihoti [Count Nikola Šubić Zrinski at Sziget] in which he described Zrinski's heroic deeds from the perspective of Pan-Slavic identity in detail. He drew on Ján Kollár's sonnet “My sme dali Uhrům Zríniho" [We gave Zrinski to the Hungarians] included in his Slávy dcera ([The daughter of Sláva] final version published in 1852). The sonnet asserts that the Slavs left Zrinski to the Hungarians, just like they left Ján Hus to the Germans and Nicolaus Copernicus to the Italians and that they also gave up Zrinski's legacy. Sládkovič, in his epic poem, returned Zrinski of Szigetvár to the Slavic Pantheon, based on the text of Zrinski the poet. 
Z áznamy a výklady o osobnosti a hrdinských činoch Mikuláša IV. Zrínskeho (1508-1566, chorvátska podoba mena Nikola Šubić Zrinski, mad'arská podoba mena Miklós Zrínyi), ktorý sa vyznamenal v bojoch proti Turkom a zomrel pri obrane pevnosti Sihot' (mad'arsky Szigetvár) v roku 1566, a jeho pravnuka Mikuláša VII. Zrínskeho (1620-1664, chorvátsky Nikola Zrinski, mad'arsky Miklós Zrínyi), mad'arského barokového básnika 17. storočia, vojvodu a politika s totožným menom ako jeho predok, vplývali v Uhorsku niekol'ko storočí na konštruovanie politickej ideológie a národného povedomia medzi Mad'armi a národmi nehovoriacimi po mad'arsky (Hausner 2016). Habsburský patriotizmus a uhorský (hungarus) patriotizmus sa hlásili k obom Zrínskym od druhej polovice 17. storočia. Pre ustálenie ich miesta v ríšskom patriotizme zohrali dôležitú úlohu historici 18. storočia, ktorí ich predstavili ako ochrancov katolíckej viery a obhajcov jednotnej habsburskej monarchie. Diela 19. storočia vyjadrujúce ríšsku identitu zarad'ovali sihotského hrdinu a jeho pravnuka-básnika a politika-medzi známych Rakúšanov v ríšskom zmysle, nakol'ko boli významnými osobnostami habsburskej ríše a slúžili cisárovi s bezhraničnou lojalitou. V súlade $s$ týmto názorom vydal v roku 1807 Joseph Hormayr životopis sihotského M. Zrínskeho v nemčine a Johann Peter Krafft namal'oval vo Viedni obraz o Zrínskeho poslednom boji na Sihoti. O niekol'ko desat'ročí neskôr zostala pre viedenské ríšske povedomie prijatel'ná iba postava sihotského Zrínskeho, jeho pravnuk bol zbavený tejto úlohy po tom, ako vyšli najavo nové fakty svedčiace o jeho konflikte s viedenským vojenským vedením, najmä s Raimundom Montecuccolim (Klaniczay 1952: 64). V sieni slávy viedenského Vojenského múzea dostal miesto iba sihotský Zrínsky, ale v rokoch 1864-1865 zobrazili mad'arskí sochári Miklós Vay a Miklós Izsó na jeho soche aj črty tváre jeho pravnuka, ktorého takýmto spôsobom „prepašovali“ do panteónu.

Básnik Zrínsky mal v tom čase prvoradý význam v mad'arskom stavovskom ideologickom nacionalizme. V prvej polovici 19. storočia, v dôsledku zmien kultúrnych paradigiem v celej Európe, sa spoločná tradícia Zrínskeho v mnohonárodnej habsburskej ríši rozpadla-v Uhorskom král'ovstve a Chorvátskom král'ovstve vznikli paralelné národné diskurzy. Pri vzniku modernej politickej myšlienky o mad'arskom národe zohrávali významnú úlohu historiografia, literatúra a filológia. Postavy oboch mužov, M. Zrínskeho a jeho pravnuka, sa stali dôležitou súčastou národných symbolov. Podnetom pre rozvíjanie ich symbolického odkazu boli na začiatku 19. storočia dve edície Ferenca Kazinczyho, ktorý v roku 1816 vydal epos pravnuka Obsidio Szigetiana pod názvom Szigeti veszedelem (Nebezpečenstvo v Sihoti, napísaný 1647 , vydaný vo Viedni 1651 ako súčast' zbierky Adriai tengernek Syrenaia, v chorvátčine vydaný v roku $1660 \mathrm{v}$ Benátkach pod názvom Adrianskoga mora sirena) a v roku 1825 uverejnil životopis sihotského M. Zrínskeho (Neubauer 2002: 230). Vd'aka tomu objavili spisovatelia a myslitelia význam Zrínskeho tradície v epoche reforiem. Súvekí uhorskí/mad'arskí politici Miklós Jósika, Jozef Eötvös a László Szalay videli v mladšom z dvojice Zrínskych politika, ktorého považovali za predchodcu svojich vlastných reforiem. Jeho postava 
434 dostala protihabsburské politické črty. V revolučných rokoch 1848 - 1849 sa stal Zrínsky symbolom mad'arského úsilia o získanie autonómie a protikladom habsburských politických snáh. Tento obraz sa ešte viac posilnil po páde revolúcie, ked'boli v roku 1853 vydané Zrínskeho politické state.

Interpretácia Zrínskeho a Zrínskych ako mad’arských národných hrdinov stála v protiklade s rakúskym aj chorvátskym vnímaním. V Chorvátsku bol silný kult sihotského M. Zrínskeho (Mesić 1866; Dukić 2018: 148). Na začiatku ilyrizmu a následne po vystúpení Ante Starčevića (1823-1896), zástupcu panslavistickej platformy, sa stal ešte radikálnejším politický prístup namierený proti Rakúsku, rakúsko-uhorskému vyrovnaniu a Uhorsku. V roku 1873 založili v Záhrebe verejný park, ktorý pomenovali po Zrínskom na Zrinjevac, ale neskôr, ked' sa Fran Krsto Frankopan (1643-1671) a Petar Zrinski (1621-1671), po neúspešnom sprisahaní proti rakúskemu cisárovi Leopoldovi I. popravení Habsburgovcami vo Viedenskom Novom Meste, stali súčast'ou chorvátskeho národného mýtu, umiestnili do parku Frankopanovu sochu (Artuković 1997; Jankovič 2010: 164).

V pamäti slovanského obyvatel'stva Uhorska, a to nielen u južných Slovanov, bola prítomná postava obrancu hradu Zrínskeho od 16. storočia. Už v roku 1566 ospevoval anonymný autor (pravdepodobne účastník obliehania) v slovakizovanej češtine hrdinskú výdrž obrancov pevnosti a neskorší pád Sihote do tureckých rúk v piesni O Sigetskom zámku (Pjseň o Siğetském zámku... 2010: 33-46). Výskumy v 20. storočí poukázali na to, že táto historická pieseň sa obsahovo podobá na mad'arskú báseň rovnako neznámeho pôvodu História az Szigetvárnak veszéséröl (Sziklay 1962: 73, 78; Csanda 1963: 64). V slovenskej literatúre získala postava Zrínskeho rozhodujúci význam v 19. storočí, v čase silnejúcich ideí panslavizmu a slovanskej vzájomnosti. Dve rozličné verzie slovenskej piesne zo 16. storočia spopularizoval v tridsiatych rokoch 19. storočia Ján Kollár (1793-1852), ked' ich zaradil do svojej zbierky Národné spievanky (1834). Ich uverejnenie bolo pre Kollára dôležité, nakol'ko Zrínskych spomína trikrát aj vo veršoch svojej básnickej skladby Slávy dcera $(1824,1832$, konečná verzia 1852). V jednom sonete vymenoval body ohraničujúce územia obývané Slovanmi, pričom po vymedzení severnej a východnej hranice odkázal na južných Slovanov cez prastarú pevnost' Zrínskych: „Torun, kde jsou kosti Koperníka, / prahy Dněpru, chobot Chvalinský, Zrin, / Plač - to vše rázem v oku zniká" (Kollár 1852: 274). V inom sonete spomína Zrínskeho sluhu Črenka: „Črenko čeledínem Zríniho“ (Kollár 1852: 491). V tretom speve Dunaj v sonete 329 nakoniec zdôraznil myšlienku, že „My jsme dali Uhrưm Zríniho" (Kollár 1852: 329), čím vyzdvihol jednak hrdinov slovanský (chorvátsky) pôvod (,, i my máme z kmene vlastního / mužủ, kterým sluši čest a díka“; Kollár 1852: 329) a súčasne skutočnost', že slovanské národy umožnili privlastnit' si jeho odkaz cudzím, konkrétne Mad'arom (Uhrom), rovnako ako odovzdali Nemcom Jana Husa a Mikuláša Kopernika Talianom. Kollárov akcent na chorvátsky pôvod Zrínskych a ich miesto v panslavistickom kruhu neskôr rozvinuli viacerí slovenskí autori 19. storočia (Jankovič 2011: 7-23, 48-53).

Okrem J. Kollára prispel k rozšíreniu slovenského kultu Zrínskeho aj Štefan Moyzes (1797 - 1869) (Jankovič 2010: 163-170; Sesar 2020), ktorý pôsobil od roku 1830 ako profesor akadémie v Záhrebe a mal dobré vztahy s vedúcimi osobnost'ami ilyrizmu - Ljudevitom Gajom (1809-1872) a Stankom Vrazom (1810 -1851). Počas jeho pôsobenia v Chorvátsku mala naňho vel'ký vplyv chorvátska 
tradícia Zrínskeho, sám prispel v roku 1836 do nového záhrebského vydania ly- 435 rickej básnickej zbierky Odiljenje Sigetsko, ktorú jej autor Pavao Ritter-Vitezović (1652 - 1713) vydal pôvodne v roku 1684 v Linzi. V úvode zväzku Moyzes prerozprával na základe chorvátskej národnej ideológie pád Sihote a činy M. Zrínskeho a obrancov hradu (Moyses 2010: 20-22). Medzi svojimi zdrojmi uvádzal slovinského prekladatel'a 16. storočia Samuela Budinu (medzi 1540 a 1550 - po 1571), ktorý v roku 1568 sprístupnil chorvátsku kroniku Ferenca Črnka História Sihote, dielo mad'arského básnika a historika Mikuláša Istvánffyho (1538-1614) Historiarum de rebus Ungaricis libri XXXIV, vydané pôvodne v latinčine až po smrti autora v roku 1622, a J. Kollára, ktorého najdôležitejšie slová o Zrínskom aj citoval: „My jsme dali Uhrům Zríniho. "K chorvátskemu prostrediu mal Š. Moyzes blízko aj po svojom odchode z Chorvátska. ${ }^{1}$ Silnejúca myšlienka ilyrizmu v dobovom slovenskom národnom hnutí sa tak dá spojit' s jeho pôsobením po návrate domov, kde podporoval formovanie slovenského národného povedomia (Molda 2018; Sesar 2020). V slovenskom prostredí predstavoval Š. Moyzes významnú autoritu, ale Mad'ari považovali za podvratné, ak niekto rozširoval medzi Slovanmi panslavistické myšlienky (Borovszky 1903: 433).

V septembri 1866 uplynulo tristo rokov od smrti sihotského M.Zrínskeho, čo mimoriadne silno aktivizovalo chorvátske vedecké a umelecké kruhy. V Záhrebe publikoval Matija Mesić (1826 - 1878) monografiu o živote obrancu hradu Zrínskeho (Dukić 2018: 156), syn L. Gaja Velimir (1845-1902) napísal o Zrínskom báseň Nikola Zrinski a spolu s otcom dal publikovat' dielo chorvátskeho renesančného básnika Brneho Krnarutića (1515-1573) Vazetje Sigeta grada, napísané v rokoch 1568 - 1572, no vydané v Benátkach v roku 1584 až po smrti autora, filológ a jazykovedec Vatroslav Jagić $(1838$ - 1923) sa zaoberal eposom Petra Zrínskeho (1621 - 1671) o d'alšom martýrovi z rodiny Zrínskych, ktorého Habsburgovci popravili (Angyal 1959: 79-80).

Jubileum však rezonovalo nielen v Chorvátsku, ale aj v slovenskom prostredí. Predstavitelia Matice slovenskej sa dohodli na svojom rokovaní 2. mája 1866 v Turčianskom Svätom Martine, že k výročiu usporiadajú oslavu a vydajú pamätnicu. Na spoluprácu bol oslovený aj Andrej Sládkovič, významný básnik romantickej školy, ktorý 20. júla 1866 písal v liste Augustovi Horislavovi Krčmérymu, že svoju prácu - historický epos Gróf Mikuláš Šubić Zrínsky na Sihoti, žánrovo označený ako „pejma epická“ - už poslal objednávatel'om: „Bolesti pôrodné pominuli a mat' je v šestinedeliach. Zrínskyada je okúpaná, povitá a daná do Findethausu, t. j. sekretariátu matičnému doručená k upotrebeniu patričnému“ (Kraus 1970: 229). Ako uvádza Cyril Kraus v komentári k druhému zväzku Sládkovičovho diela z roku 1961, „kedy Sládkovič pracoval na svojej básni, objasňuje nám jej rukopis (28 listov rozmerov 34 × $21 \mathrm{~cm}$ )“, kde je ceruzkou dopísaný dátum „od 20 Jun. do 16 Julia“" (Sládkovič 1961: 408).

1 Medzi rokmi 1849-1850 sa Š. Moyzes zdržiaval vo Viedni ako dôverník Josipa Jelačića a zúčastnil sa rokovaní o chorvátskych záležitostiach (Molda 2018: 95). Svoje skúsenosti z Chorvátska dokázal zúročit aj počas svojho pôsobenia v Hornom Uhorsku. 12. decembra 1861 predstúpil na čele slovenskej delegácie pred cisára Františka Jozefa, aby mu predložil Memorandum slovenského národa. 3. augusta 1863 sa stal prvým predsedom Matice slovenskej, ktorá vznikla podl'a vzoru Matice ilirskej založenej v Záhrebe v roku 1842, teda v čase, ked'Moyzes pôsobil v Chorvátsku. 
Samotná oslava sa konala 11. septembra 1866 v Banskej Bystrici. Vznikla publikácia Pamätník Matice Slovenskej ku tristoročnej oslave Mikuláša Šubica Zríňského, konanej na Slovensku v rozsahu stopätnást' strán, v ktorej bola okrem Sládkovičovej dlhej poémy, podrobne opisujúcej okolnosti prepadnutia Sihote, hrdinské činy Zrínskeho a obrancov hradu a nakoniec božské odpustenie, zaradená aj báseň Jozefa Miloslava Hurbana Zrínsky na Sihoti, tematizujúca motív viny Jána Žigmunda Szapolyaiho na vzniknutej situácii, hrdinskost' obrancov hradu, Sulejmanovu smrt'a jeho konečný výpad (Hurban 2010: 108-120). Ďalšie príspevky pamätnice sa venujú udalostiam, ktoré predchádzali sihotským bojom, a dobe a životu M. Zrínskeho. Publikáciu uzatvára d'alšia Sládkovičova báseň Zbit'-lebo mriet'!

Sládkovičov záujem o Zrínskeho však nebol len vecou realizácie priamej objednávky výboru Matice slovenskej, ${ }^{2}$ ale ukazuje aj na jeho vlastnú ideovú orientáciu. ${ }^{3}$ Básňou Gróf Mikuláš Šubić Zrínsky na Sihoti sa autor zapojil do súvekej diskusie, komu oslavovaný hrdina vlastne patrí. Zároveň ňou reagoval na predchádzajúce literárne spracovania zvolenej témy. Pri jej analýze zameranej na motivické prieniky s inými textami vystupujú do popredia dva hlavné inšpiračné zdroje: Sládkovičovým východiskom bol nepochybne epos básnika Zrínskeho Szigeti veszedelem vo vydaní z roku 1816, druhým prameňom, z ktorého vychádzal, bola história obliehania hradu, ktorú kronikársky podrobne zaznamenal v 16. storočí komorník hradného kapitána Franjo Črnko (Ferenc/Ferenac Črnko) ${ }^{4}$ - nie však jej chorvátsky originál Podsjedanje i osvojenje Sigeta, ale latinsko-nemecký preklad od Samuela Budinu z L'ubl'any Historia Sigethi totius Sclavoniae fortissimi propugnaculi quod a Solimanno Turcarum imperatore nuper Captum Christianisque ereptum est ex Croatico sermone in Latinum Conversa, per M. Samuelem Budinam Labacensem, vydaný vo Viedni v roku 1568 (Budina 2019: 133-200). Kým u Budinu sa vyskytujú bezprostredné historické pramene, Zrínsky čerpal z latinskej histórie Istvánffyho a chorvátskej básne Brneho Krnarutića.

Sládkovičova báseň obsahuje vel'a epizód a motívov, ktoré sa vyskytujú $\mathrm{v}$ dielach Zrínskeho aj v dielach Budinu, sú v ňom tiež pasáže, ktoré vychádzajú iba zo Zrínskeho, a zároveň také epizódy, ktorých prameňom je len Budinov preklad. Navyše, Sládkovič využil aj čast' Kollárom zverejnenej epickej piesne

2 Ako uvádza chorvátsky literárny vedec Marijan Šabić v súvislosti so Sládkovičovou skladbou o Zrínskom, „pravdepodobne práve biskup Moyses ho podnietil k napísaniu epickej básne, ktorá ani poeticky, ani žánrovo nezapadala do jeho dovtedajšieho opusu“ (Šabić 2021: 147).

3 O politických názoroch A. Sládkoviča písal napríklad mad'arský slovakista László Sziklay, podla ktorého niekedy hladal možnosti spolužitia s Mad'armi, inokedy zas presadzoval panslavistické myšlienky (Sziklay 1962: 330-348).

4 Predložená interpretácia je výsledkom porovnávacieho čítania všetkých troch diel. Vo vydanej korešpondencii A. Sládkoviča nie sú žiadne básnikove vyjadrenia k tejto téme, neexistujú teda priame dôkazy o jeho inšpiračných východiskách. Doterajší bádatelia sa bližšie nezaoberali otázkou pramennej bázy tejto Sládkovičovej epickej básne s historickým námetom ani jej intertextuálnymi odkazmi, napríklad L. N. Zvěrina vo svojom úvode k vydaniu skladby v roku 1929 konštatoval, že „stvoril Sládkovič vo svojej pejme, odhliadnuc od reminiscencií z biblie, Homéra a Vergila, dielo zväčša samostatné“ (Zvěřina 1929:11-12). 
v slovakizovanej češtine zo 16. storočia, ${ }^{5}$ no viac sa k nej už nevzt'ahoval, pretože

jej dejová línia sa privel'mi odlišovala od jeho vlastnej kompozície a uhla pohl'adu (o čom svedčí najmä úplné vynechanie výpadu a umiestnenie smrti Zrínskeho do nedôstojných okolností). ${ }^{6}$

Z epizód, ktoré sa nachádzajú v dielach všetkých troch autorov - Zrínskeho, Budinu aj Sládkoviča-, sa dá uviest' útok pri Šiklóši. Kým Budina a Zrínsky ho opisujú podrobne, Sládkovič približuje príchod uhorských vojakov a zrážku s Turkami iba v dvoch strofách, ked' boje opisuje ako vzdialený pozorovatel', ktorý sleduje oblak prachu a záblesky mečov (Budina 2019: 178-18o; Zrinyi 1984: tretí spev, strofy 44-114; Sládkovič 2010: 72). Neskôr, ked' je už hrad obklúčený a je zrejmé, že zrážka bude nevyhnutná, zavolá si k sebe Zrínsky svojich kapitánov a zloží prísahu na obranu hradu. Tá odznie vo všetkých troch dielach. Priame spojivá sú badatel'né najmä medzi podaním Budinu a Sládkoviča, a to napriek zjednodušeniam slovenského básnika. ${ }^{7}$ Zjavná je tiež zhoda v časti, ked'sa M. Zrínsky pripravuje na nastávajúci boj. ${ }^{8}$

Iba u Budinu a Sládkoviča sa vyskytuje napríklad scéna s listom:v diele slovenského básnika na začiatku deja drží kapitán v ruke list od posla prinášajúceho zlé správy (Sládkovič 2010: 70). Nie je vysvetlené, odkial' prišiel posol a čo obsahuje list. Zrínskeho epos Szigeti veszedelem neobsahuje tento detail, ale u Budinu podáva druhý posol Zrínskemu list so správami o pohybe tureckej

5 Pjseň o Siğetském zámku je príbeh o jednom z obrancov hradu a jeho manželke. Ked' manžel videl, že situácia je beznádejná, chcel zachránit' svoju manželku pred zneuctením. Vytiahol preto svoj meč a chytil ju za krk, aby jej mohol odrezat' hlavu. Žena však prosila manžela, aby ju nezabil, radšej nech jej dá husárske šaty a meč. Turci však hned' spoznali na koni postavu ženy a chceli ju zajat.'Žena podrezala sedem Turkov, potom ju strelili do hrudníka a spadla z koňa (Pjseň o Siğetském zámku... 2010: 43-44). V Sládkovičovej básni sihotskí muži vidiac svoju beznádejnú situáciu rozhodnú, že nenechajú svoje manželky padnút' do tureckých rúk a zneuctit', preto ich radšej zabijú mečom. Ked' Madlena videla, čo sa chystá, poprosila mužov, aby meče znečistené tureckou krvou nevnorili do ženských sŕdc, ale radšej vložili aj do ich rúk meč, aby mohli zomriet' v spoločnom boji (Sládkovič 2010: 93-94). Dejová podobnost' je tu zjavná, na rozdiel od eposu M. Zrínskeho, v ktorom vystupuje žena v mužskom rúchu - Szigeti veszedelem (Zrínyi 1984: trinásty spev, strofy 6-16).

6 Ked' Turci dobyli Sihot', po troch dňoch našli ležiaceho Zrínskeho, vyviedli ho z izby a stali mu hlavu (Pjseň o Siğetském zámku... 2010: 44-45).

7 Text Budinovho slubu: ,Jja, Mikuláš, gróf Šubić zo Zrínu, prisahám najprv najlepšiemu a najmocnejšiemu Bohu, potom veličenstvu cisárovi, našim najvyšším svetským vrchnostiam a trpiacej vlasti, a nakoniec vám, udatným a odvážnym mužom, ktorí ste sa tu zhromaždili. Nech mi pomáha Boh Otec, Jeho Syn a Duch Svätý, a Svätá trojica a jeden Boh, že vás nikdy neopustím, s vami bud' zvítazím, bud' umriem, a dovtedy nech sa stane čokolvek dobrého či zlého, prežijem spolu s vami“ (Budina 2019:183; z mad'arčiny preložila I. P.). Text Sládkovičovho slubu: „Ja, bán Mikuláš, gróf Šubić zo Zrínu, / prisahám Bohu živému, - král'ovi, - / úbohej vlasti a svojmu vojínu: / že Sihot túto nepoddám vrahovi, / neopustím trón, vieru, nie otčinu, - / žit i mriet za to vždycky súc hotový: / jak to splním, tak ráč mi pomáhati / Boh Otec a Boh Syn a Boh Duch Svätý“ (Sládkovič 2010: 34).

8 V Sládkovičovom spracovaní už svitá, ked' kapitán prikáže, aby priniesli jeho modré a zlaté šaty zo zamatu, a následne si ich oblečie. Prikáže sluhovi Črenkovi, aby prichystal do dvoch vriec dukáty, ale aby medzi nimi neboli turecké peniaze. Do záhrenia si vloži klúč od hradu. Vyberie a priviaže si na pás meč svojho otca. Vytiahne z puzdra meč a puzdro nechá na stole (Sládkovič 2010: 95-96). Táto epizóda sa okrem niekol'kých detailov zhoduje s prípravou na boj v d'alších dvoch dielach. V diele Szigeti veszedelem Zrínsky znesie dohromady svoje poklady a zapáli ich. Vyberie si oblečenie, ktoré používa len na výnimočné sviatočné dni. Rozdelí sto zlatých a dá ich do dolománu. Vyberie si jeden zo svojich nespočetných mečov a pripne si ho. U Budinu dá Zrínsky priniest' sto zlatých forintov, rozpára mentieku zo zamatu a peniaze vloží medzi zamat a podšívku. Črenko na príkaz grófa prinesie štyri l'ahké meče, aby si ich kapitán vyskúšal, Zrínsky si vyberie otcov meč (Budina 2019: 194-195). 
438 armády (Budina 2019: 178). Spojivá sú aj pri opise stavby mosta cez Drávu, ${ }^{9} \mathrm{kde}$ prírodný živel tri razy zničil most. Motív trikrát opakovaného prekazenia ludskej vôle prírodnými silami a zničenie mostu záplavami pripomína sčasti Vergíliov epický vplyv, sčasti topickú tradíciu Xerxesovho budovania mostu, ktorá vedie spät' k Herodotovým časom.

So Zrínskeho dielom Szigeti veszedelem spájajú Sládkoviča napríklad motívy modlitby ${ }^{10}$ či prorockej veštby. ${ }^{11}$ Kým predpovedanie osudu sa u S. Budinu nevyskytuje vôbec, $v$ Szigeti veszedelem sa nachádza v inej časti deja (predtým než armáda obliehala pevnost'). ${ }^{12}$ Záver Sládkovičovej básne - anjelská armáda prichádzajúca pre duše hrdinov - je priamou alúziou na Szigeti veszedelem..$^{13}$

Prirodzene, stručným zhrnutím prameňov a vplyvov nie je možné vyčerpat poetické hodnoty a vlastnosti Sládkovičovho historického eposu. Napríklad kapitánov sen o st'atí hlavy svätého Jána Krstitel'a sa zdá byt' jeho vlastnou inováciou. ${ }^{14}$ Zasadením básne do kontextu dostupných prameňov sa ukazuje, že slovenský básnik použil mad'arský epos M. Zrínskeho a dobovú historickú správu S. Budinu. Dôležité je však zistenie, že motívy z oboch prameňov boli prepísané, doplnené a prepracované podl'a panslavistickej ideológie. Panslavizmus je zretel'ný na tých miestach, kde Sládkovič zmenil zdroje, rozšíril a interpretoval rad udalostí. Pri porovnaní s J. Kollárom sú jeho zmeny významné a dôležité. Rámcová štruktúra prvej a poslednej slohy vyjadruje, že sihotského Zrínskeho, ktorý je pre svoj chorvátsky pôvod členom slovanskej rodiny a teraz

9 Hassan-beg dostane Sulejmanov rozkaz a zlatočervenú šatku so šnúrou zo zamatu. Okamžite začne pripravovat stavbu mosta, ale „trikrát už brvná breh o breh pripäli / a trikrát brvná pošli dolu vodou“ (Sládkovič 2010: 74). V diele Budinu sa beg volá Hamza, ktorý dostane príkaz od sultána na výstavbu mosta pod hrozbou, že ak nesplní jeho príkaz, nastoknú ho na kôl pred vlastným domom. Beg začne výstavbu mosta: najprv postaví most ned'aleko od Újtó, ale v noci ho záplavové vlny rozbijú a rozmetajú; druhý raz postaví most nižšie na Dráve, ale aj ten cez noc znesie voda; tretí raz sa pokúsi postavit most pri Osijeku, ale nemôže ho dokončit pre silný prúd. Beg Hamza vyšle posla k sultánovi so zlou správou o neúspešnej výstavbe mosta. Na to sultán pošle spät šatku zo zamatu so zlatým písmom na okraji so správou, že ak most nedokončí, na tej šatke bude obesený. Preto hned' začne znovu stavat' most, ktorý dokonči za desat' dní (Budina 2019: 181).

10 U Zrínskeho kapitán ako obvykle na úsvite kl'ačí pred svätým krížom a obracia sa na Boha (Zrínyi 1984: druhý spev, strofy 64-78). U Sládkoviča po vítazstve pri Šiklóši zavládol v noci na hrade mier, hrdina klačí na hradbách a prosí Boha o pomoc: „Ukrižovaný! smiluj sa nad nami! / Nech Otca hnev sa na nás nevylieva! - / Shliadni na krajny tejto krvobrody! / Zkries palmy zvädlé! - pomiluj Gospodi!“ (Sládkovič 2010: 73). 11 U Sládkoviča počas tureckého obliehania Sihote prišli veštci, ktorí sa hodinu dívali na súhvezdia a nebo, potom vyslovili veštbu: „soka môjho pretne meč plamenný, / hrob prisúdený obkročit' sa nedá, / padlým isté sú raje Mahomeda!“ (Sládkovič 2010: 78).

12 Sulejman zvolal diván a rozhodol sa zaútočit na Sihot', ale najskôr si zavolal veštcov a kňazov. Kňazi považujú za zlé znamenie, že mŕtvoly oviec začali trhat' menšie orly na kusy, potom ale priletí vel'ký čierny orol, ktorý odoženie orly a sám nechá mŕtvoly na pokoji. Sultán neverí kňazom, ktorí sa ho snažia chránit pred pochodom na Sihot'. Sultán si vysvetlí udalosti po svojom, tvrdí, že vel'ký čierny orol nejedol z tiel mŕtvych oviec, pretože chce jest' z krestanských tiel (Zrínyi 1984: štvrtý spev, strofy 66-80).

13 Sládkovič smrt' Zrínskeho opisuje takto: mad'arskí a chorvátski hrdinovia, obrancovia hradu, beznádejne bojovali s Turkami. Zrínskemu prepichli hrud', ale on si hlbokú ranu zakryl a d'alej povzbudzoval svojich mužov do boja. Chytil jedného Turka a spolu spadli do hlbokej jamy. Anjeli sa pozerajú z neba na obetavý boj obrancov hradu a spievajú chválospevy. Po skončení boja jeden turecký bojovník tajne vtiahne do hlbokého hrobu Zrínskeho telo a hlavu, a tak ho symbolicky pochová. Dušu M. Šubića Zrínskeho zdvihnú anjeli do neba (Sládkovič 2010: 101-104). V diele Szigeti veszedelem po tom, čo Zrínsky zabije sultána Sulejmana, sa Turci k nemu neodvážia približit', a preto ho zastrelia. Armáda anjelov pristane na zemi a grófovu dušu zdvihne do neba (Zrínyi 1984: pätnásty spev, strofa 106).

14 Je dôležité pripomenút ranonovoveké dielo chorvátskej literatúry, báseň Marullusa (Judita, 1521) a príbeh Judity, ktorá odsekla hlavu Holofernesovi. 
po tristoročnej väzbe sa môže vrátit' domov, aby učil svoj národ, Slovania nikdy 439 nedali Mad'arom, ale tí si ho od nich vzali.

\author{
„Tristo rokov! Tristo rokov v zajatí \\ ležal Mikuláš gróf Šubić od Zrína! - \\ Už ide domov, - tešte sa, Horváti, \\ už ide, - teš sa Slavianska rodina! - \\ My ,Uhrom'sme ho nedali; - hl'a, vráti \\ to, čo vzali nám - nestranná dejina! - \\ Hej, učit ide svoj národ vojvoda: \\ Kde žit' nevol'no, tam umret'sloboda! -“ (Sládkovič 2010: 67)
}

Pre Sládkoviča je vel'mi dôležitá porážka pri Moháči, ktorú Zrínsky v epose vôbec nespomína, ale u Sládkoviča je jedným z opakujúcich sa motívov. ${ }^{16}$ Slovenský romantický básnik vo svojej poetickej vízii opisuje Moháč ako obklúčenú, strašidelnú podzemnú pevnost', kde v centrálnom priestore sedia pri stole duchovia - biskupi, kňazi, šlachtici a na jeho čele sedí král', ktorý ma na oblečení blato a piesok. Král'ovský duch sediaci v zablatenom oblečení nad plesnivým a pokazeným jedlom je L'udovít II. Jagelovský, český a uhorský král', po ktorého smrti pri Moháči už nikdy nesedel slovanský vládca na uhorskom tróne. Cudzí, rakúski králi sa navyše nespoliehali na svojich slovanských poddaných, ale privilegovali pyšné a násilné uhorské stavy. Sládkovič s vel'kou otvorenost'ou hovorí aj o tomto. Už tu sa jeho text výrazne líši od textu Zrínskeho, ked'vymenúva príčiny, ktoré vyvolali Boží hnev proti Mad'arom. V diele Szigeti veszedelem sú príčinou Božieho trestu rôzne druhy morálnych hriechov. ${ }^{17}$ Podl'a Sládkoviča je jediným dôvodom Božieho hnevu povýšenost' a nezhoda medzi Mad'armi. V básni sa opakovane vyskytuje kontrast zhýralého, anarchistického pohana a morálne žijúceho krestana. ${ }^{18}$ Sládkovičove aktuálne názory z polovice šest'desiatych rokov 19. storočia vyjadrujú dve strofy, v ktorých samoúčelné vojenské ničenie a pokojná tvorivá práca nesymbolizujú pohanský a krestanský svet, ale svet Mad'arov a Slovákov.
„Stavali mestá, - tí hnijú bez slávy,
rúcali mestá, - tých velebia deje,
za nič má svet tých, čo svätili hlavy,
a tým, čo hlavy stinali, dobre je!
Pri hrobe tichých niksa nezastaví,

15 V záverečnej strofe je v šiestom verši namiesto výrazu „nestranná dejina“ spojenie „ruka Hospodina“ (Sládkovič 2010: 107).

16 Najprv sa hovorí o tom, ako po vojenskej prehliadke na poli Šiklóš povzbudzuje M. Šubić Zrínsky svojich mužov, ktorí sa pripravujú na súboj. Spomína na porážku, ktorú utrpeli pri Moháči, a na tých, ktorí tam zomreli alebo ich odvliekli do Istanbulu (Sládkovič 2010: 71). K Moháču sa vracia aj po tom, čo Turci podpálili vonkajšie časti hradu (Sládkovič 2010: 88).

17 „Sok feslett erkölcs és nehéz káromlás, / Irigység, gyülölség és hamis tanácslás, / Fertelmes fajtalanság és rágalmazás, / Lopás, emberölés és örök tobzódás“ (Zrínyi 1984: prvý spev, strofa 10); v slovenskom preklade: „Vel'a zbytočnej morálky a silného rúhania, / závist', nenávist' a falošná rada, / ohavné smilstvo a ohováranie, / krádež, vražda a večné hýrenie“ (Sládkovič 2010: 68).

18 Takýmto príkladom je epizóda, ked' po veštení vypukne vel'ký nepokoj v tureckom tábore, naproti tomu v Sihoti vládne svätý pokoj a tichá modlitba (Sládkovič 2010: 79). 
výbojcov chvália sochy a trofeje, -

hej, títo pevcov a pejmy pálili

a pevci, pejmy-paličov chválili!

\author{
Súd', Hospodine Bože, súd' národy! \\ Pých a a krivda obsadili tróny, \\ ach, zle pobožným, zle sa dobrým vodí, \\ päst'a násilie prijíma poklony! \\ Či ešte časom Tamerlan vývodí? - \\ Trpís, Bože, viac, mimo dva Zákony? \\ Ej, ticho, duša, blízko doba súdu, \\ a ponížení povýšení budú!" (Sládkovič 2010: 100)
}

Sládkovič dôrazne vyjadruje svoje názory súvisiace s panslavistickou identitou o cnostiach a historickom povolaní Slovanov, ktoré sú namierené proti vlastenectvu habsburskej ríše a uhorskému (hungarus) vlastenectvu. ${ }^{19}$ Jeho neskoré práce nepochybne potvrdzujú koniec uhorského povedomia. Pre formulovanie svojej ideovej koncepcie využil v rámci zvolenej historickej témy tak literárne, ako aj historické pramene. Kým literárne diela čítal v mad'arčine a slovakizovanej češtine, historické dokumenty mu sprostredkovali chorvátske texty či preklady v latinčine a nemčine. Je pozoruhodné, že obsahové elementy a aspekty mad'arského barokového národného eposu zužitkoval v slovenskej epickej básni zameranej na posilnenie slovanskej identity a slovenského národného povedomia.

\title{
Pramene
}

BUDINA, Sámuel, 2019. A híres szigeti vár bevételének históriája... 1568: Német változat. Preklad József Kelenik. In FODOR, Pál, ed. Szigetvár 1566. évi ostromának igaz története. Budapest: Magyar Tudományos Akadémia Bölcsészettudományi Kutatóközpont, s. 177-200. ISBN 978-96-341-6136-3.

HURBAN, Josef Miloslav, 2010. Zrínsky na Sihoti. In JANKOVIČ, Ján, ed. Legenda o grófovi Zrinskom II. Chrestomatia. Bratislava: Veda, s. 108-120. ISBN 978-80-224-1157-8.

JANKOVIČ, Ján, ed., 2010. Legenda o grófovi Zrínskom II. Chrestomatia. Bratislava: Veda. ISBN 978-80-224-1157-8.

KOLLÁR, Jan, 1852. Sláwy dcera: Báseň lyricko-epická w pěti zpevich, spridawkem basní drobnějších. We Wídni: Tiskem P. P. Mechitharist.

KRAUS, Cyril, ed., 1970. Korešpondencia Andreja Sládkoviča. Martin: Matica slovenská. MESIĆ, Matija, 1866. Život Nikole Zrinjskoga sigetskoga junaka. Zagreb: Matica ilirska.

MOYSES, Štefan, 2010. Mikuláš, knieža Zrínsky. In JANKOVIČ, Ján, ed. Legenda o grófovi Zrínskom II. Chrestomatia. Bratislava: Veda, s. 7-22. ISBN 978-80-224-1157-8.

PAMÄTNÍK Matice slovenskej ku tristoročnej oslave Mikuláša Šubića Zrínskeho, konanej na Slovensku, 1866. Matičných spisov číslo 12. Banská Bystrica: tlač Karola Goríška, na sklade u Eugena Krčméryho, matičného kníhkupca.

PJSEŇ o Siğetském zámku (r. 1566). In JANKOVIČ, Ján, ed., 2010. Legenda o grófovi Zrínskom II.: Chrestomatia. Bratislava: Veda, s. 33-46. ISBN 978-80-224-1157-8.

19 Podla editorky Sládkovičovho diela Ireny Bilińskej „Sládkovičova tvorba je priam modelovým príkladom vývinu slovenského slavianofilstva, od idey kollárovskej slovanskej vzájomnosti cez inštrumentálne využívanie slovanských argumentov v boji o kultúrne a politické práva Slovákov až po podriadenie lokálneho vlastenectva nielen slovanskému, ale priam rusofilskému vlastenectvu, ktoré sa neskôr plne prejaví najmä u S. H. Vajanského“ (Bilińska 2014: 748). Inde I. Bilińska píše, že Sládkovič „po celý život si hl'adal vlastnú umeleckú cestu, ktorá by bola vhodnou slovenskou a slovanskou odpoved'ou na literárne otázky doby“ (Bilińska 2021: 94). 
SLÁDKOVIČ, Andrej, 1961. Dielo II. Edične pripravil, doslov a poznámky napísal Cyril Kraus. Bratislava: Slovenské vydavatel'stvo krásnej literatúry.

SLÁDKOVIČ, Andrej, 2010. Gróf Mikuláš Šubić Zrínsky na Sihoti. In JANKOVIČ, Ján, ed. Legenda o grófovi Zrínskom II. Chrestomatia. Bratislava: Veda, s. 67-107. ISBN 978-80-224-1157-8.

ZRÍNYI, Miklós, 1984. Szigeti veszedelem. Ed. Tibor Klaniczay. Budapest: Szépirodalmi Könyvkiadó. ISBN 963-15-2541-4.

\section{Literatúra}

ANGYAL, Endre, 1959. A szláv barokk kutatásának újabb eredményei. Helikon, roč. 5, s. 78-85. ARTUKOVIĆ, Mato, ed., 1997. Matija Mesić prvi rektor sveučilišta u Zagrebu. Zbornik radova sa znanstvenog skupa o Matiji Mesiću u povodu 170. obljetnice njegova rođenja 1826-1996: Znanstveni skupje održan 6. studenoga 1996. u Zagrebu, te 8. i 9. studenoga 1996. u Slavonskom Brodu. Zagreb-Slavonski Brod-Sveučilište u Zagrebu-Hrvatski institut za povijest - Odjel za povijest Slavonije, Srijema i Baranje.

BILIŃSKA, Irena, 2014. Romantický básnik slobody. In SLÁDKOVIČ, Andrej. Dielo. Ed. Irena Bilińska. Bratislava: Kalligram - Ústav slovenskej literatúry SAV, s. 731-749. ISBN 978-80-8101-858-9.

BILIŃSKA, Irena, 2021. Sládkovič dnes. Slovenská literatúra, roč. 68, č. 2, s. 93-96. ISSN 0037-6973.

BOROVSZKY, Samu, ed., 1903. Magyarország vármegyéi és városai (Magyarország monografiája). A magyar korona országai történetének, földrajzi, képzőmüvészeti, néprajzi, hadügyi és természeti viszonyainak, közmüvelödési és közgazdasági állapotának enciklopédiája: Bars vármegye. Budapest: Apollo Irodalmi és Nyomdai Részvénytársaság.

CSANDA, Sándor, 1963. Csehszlovák-magyar kulturális kapcsolatok. Bratislava: Slovenské pedagogické nakladatel'stvo.

DUKIĆ, Davor, 2018. The Zrinski-Frankopan Conspiracy as a National Sacrificial Narrative. Frontiers of Narrative Studies, roč. 4, č. 1, s. 146-157. ISSN 2509-4882.

HAUSNER, Gábor, 2016. Zrínyi Miklós emlékezete - The Echoes of Miklós Zrínyi. In HAUSNER, Gábor, ed.,Zrinyi-album-Zrinyi Album. Budapest:Zrínyi Kiadó-Hadtörténeti Intézet és Múzeum, s. 338-379. ISBN 978-963-327-664-8.

JANKOVIČ, Ján, 2011. Legenda o grófovi Zrínskom I. Súvislosti. Bratislava: Veda. ISBN 978-80-224-1212-4.

KLANICZAY, Tibor, 1952. Bevezető. In ZRÍNYI, Miklós, Válogatott müvei. Ed. Tibor Klaniczay. Budapest: Szépirodalmi Könyvkiadó, s. 7-66.

MOLDA, Rastislav, 2018. Štefan Moyzes, od predsedníckeho postu Matice k národnému hrdinovi. In GOLIAN, Ján - KURHAJCOVÁ, Alica - MALINIAKOVÁ, Erika - MOLDA, Rastislav, ed., Štefan Moyzes: za života a v historickej pamäti. Zborník vydaný pri príležitosti 220. výročia narodenia. Banská Bystrica: Stredoslovenské múzeum, s. 87-95. ISBN 97880-969866-6-8.

NEUBAUER, John, 2002. Zrinyi, Zriny, Zrinski or: In Which Direction Does the Gate of Vienna Open? Neohelicon, roč. 29, č. 1, s. 219-234. ISSN 0324-4652.

SESAR, Dubravka, 2020. Stjepan Moyses i obnova kulta Nikole Šubića Zrinskog. In STRIČEVIĆ-KOVAČEVIĆ, Zrinka, ed., Med Hrvati stanak Moj! Zbornik radova o Stjepanu Moysesu (1797 - 1869). Zagreb: Matica hrvatska, s. 187-198. ISBN 978-953-341-149-1.

SZIKLAY, László, 1962. A szlovák irodalom története. Budapest: Akadémiai Kiadó.

ŠABIĆ, Marijan, 2021. Andrej Sládkovič v chorvátskej recepcii. Slovenská literatúra, roč. 68, č. 2, s. 145-153. ISSN 0037-6973.

ŠÁTKOVÁ, Michaela, 2013. Ilyrizmus a myšlienka slovanskej vzájomnosti. Magisterská diplomová práca. Brno: Filozofická fakulta Masarykovej univerzity, Ústav slavistiky.

\section{Dr. Ingrid Papp}

Bölcsészettudományi Kutatóközpont Irodalomtudományi Intézet

\section{Ménesi út. 11-13 \\ 1118 Budapest}

\section{Magyarország}

E-mail: papp.ingrid@abtk.hu
TÜSKÉS, Gábor, 2019. The Memory of the 1566 Siege of Sziget and of Miklós Zrínyi in Hungarian Literary Tradition. In FODOR, Pál, ed. The Battle for Central Europe. The Siege of Szigetvár and the Death of Süleyman the Magnificent and Nicholas Zrinyi (1566). Leiden: Brill, s. 447-477. ISBN 978-90-04-39623-4.

ZVĚŘINA, Ladislav Narcis, 1929. Úvodné slovo. In SLÁDKOVIČ, Andrej. MikuláššubićZriňskyna Sihoti.Žilina:Slovenská krajina, s. 7-18. 